\title{
Future fields: introduction
}

By Tom Rice (Goldsmiths College) with the collaboration of Mette Louise Berg (University of St Andrews) ${ }^{1}$

Much has been written about the need for new and innovative fieldwork methods in anthropology since the reflexive turn of the discipline in the 1980s. New contexts for fieldwork and the re-evaluation of old theoretical assumptions have widened the anthropological gaze. As research interests of anthropologists have changed, so have the types of fieldworks that we undertake. Yet the ideal of long-term fieldwork in a rural location among non-Western peoples still exerts a powerful influence on the discipline. While traditional methods such as long-term site work and participant observation are still valid, they now must be complemented by innovative methods that respond to contemporary epistemological challenges. The very notion of 'the field' itself may need critical questioning.

While fieldwork remains the most significant rite de passage for anthropologists and one of the key identifiers of the discipline, there has been little discussion of how one goes about doing fieldwork in different kinds of fields, and what epistemological implications for the discipline different kinds of fieldwork may have. Fieldwork generates a multitude of entanglements, be they emotional, financial, professional, intellectual or ethical. It is by talking and writing about these experiences in the field that we become familiar with the experiential core of social anthropology, the richness, complexity and contradictions of relationships. The data produced through these often compromised and compromising encounters is ultimately transformed into an authoritative academic text, and these articles seek to elucidate the process through which raw experience has been translated into vehicles for the production of ethnographic knowledge.

The articles presented in this special issue of Anthropology Matters are each a response to the particular demands of a fieldwork setting. Collectively, they explain that the field is never encountered as an entity malleable to the hands and ideas or the research strategies of the fieldworker. Instead, as Mattia Fumanti explains in his contribution, it is the field which makes the fieldwork, and which, even more essentially, makes the fieldworker. The methodology courses through which we mould our concept of the field create a somewhat misleading sense of the ethnographer's agency in his or her working environment. Realistically, as these articles all demonstrate, the agency of the fieldworker is most evident in his or her choice of response to the conditions which animate the field. A kind of ethnographic versatility, rather than a rigorous and inflexible research strategy, becomes a virtue in fieldwork.

\footnotetext{
1 We gratefully acknowledge the contributions by Stefanie Lotter and Susanne Langer to this introduction.
} 
Mattia Fumanti interprets the language of methodology and of research proposals as an anthropological quest for 'authority' over the field. Drawing on the debate initiated in Writing Culture, he notes that anthropologists have been made aware of the need to pay attention to the authority of the ethnographic voice. Fumanti advocates a similar reflexivity in acknowledging the strategies through which fieldwork is realized, and the voices through which these strategies are articulated. More credence should be given, in his view, to the curious generosities of the field, rather than to the rigour and resourcefulness of the fieldworker. His points emerge from his own fieldwork experiences among the elites of a small town in north-west Namibia.

Julia Holdsworth also responds to the unruly-ness of fieldwork by challenging the implicit request for academic writing to present structure and an analytical frame. She resists this expectation in her study of Donetsk a post industrial city in Eastern Ukraine as to do so would have lead her to impose sense upon people who describe themselves as living 'non-sensical' lives. Holdsworth negotiates a kind of intellectual guilt in writing order into the essentially chaotic and disorderly life narratives of her 'informants'. The confusing circumstances of her friends leads her to question how far anthropologists should rework the 'purity' of fieldwork experiences in order to conform to rubrics of academic analysis.

Perhaps this Future Fields edition of Anthropology Matters should be seen as a celebration of a moment of open-mindedness in relation to fieldwork. The discipline seems to be enjoying a certain 'Field Good Factor' at present, in which the conceptual frameworks which have traditionally governed the vocabulary of the field have been relaxed, and anthropologists have felt more able to discuss the nature of fieldwork, and own up to their weaknesses or lack of direction in particular moments of ethnographic turbulence. At the same time, in acknowledging the unpredictable nature of the field, anthropologists have been able to elucidate the very productive turns which their work has taken in response to the unexpected. It is almost as though a collective confession, a 'Diary in the Strictest Sense of the Term' dealing with the field has been co-authored from across the discipline and is emerging through research touched with a new-found freedom of voice. However, this reflexivity towards fieldwork processes has also created a new critical depth in relation to fieldwork and the terms, which have traditionally been used to construct it.

Thus Giovanna Bacchiddu, describes the emotional turmoil she experienced and the complex social skills that she needed in order to make friends and fit into her field setting, a small island in southern Chile. After returning, she found a whole new set of analytical and intellectual skills were needed in order to make sense of her ethnographic data. Bacchiddu's article draws out the tension between the unruly and messy field in which she had become emotionally entangled, and the scholarly demand for clarity and detachment. These issues are perhaps even more crucial to the short-term fieldworker. In David Clark's discussion of his research about Jewish museums in Bologna, he seeks to elucidate the fieldwork 'habitus', taking us through a step-by-step account of what he describes as the 'do's and don'ts' of fieldwork. In contrast to the initial strangeness of Bacchiddu's fieldsite, Clark's experiences were eased by feelings of 'continuity' and 'belonging' stemming from his membership of the Orthodox Jewish community in London.

In her article on Cyberethnography as Home Work, Adi Kuntsman envisages her own 'fieldsite' (this in itself becomes a problematic term, she argues) as a conceptual entity suspended in a complex web of locations and dislocations. She observes that 
cyberethnography moves the discussion and practice of fieldwork 'away from distinctions between native and non-native anthropologists, between going away, going home and going online; or between discursive and physical fields and on and off-line spaces'. Drawing on her research with Russian speaking gay, lesbian, bisexual and transgender immigrants, her article explores the convolutions and complexities which make homemaking in cyberspace such a critical challenge for a discipline which is increasingly sensitive to ideas of social, geographical and political positionality for both the fieldworker, and those among whom he or she works.

Ambiguities about home and away, subject and object, are also central to Akbar Keshodkar's article. These were issues which he did not anticipate before leaving for the field. Keshodkar arrives in Zanzibar to be instantly identified as Zanzibari Asian though he never lived there and sees himself as an American of Asian descent. This racial-cum-ethnic identification conflicts with his research interest as it circumscribes his social relations and therefore his field of enquiry. In Keshodkar's case, finding a viable role as a fieldworker thus requires considerable identity work on his part.

It is precisely 'working' itself, which becomes the focus of Adam Kaul's contribution. He points out that employment and paid work have traditionally been discouraged as antithetical to ethnographic integrity, paid labour tending to implicate the anthropologist in a network of potentially compromising power relations. However, Kaul found that working behind a bar in the tourist town in which he was conducting his research allowed him access, and created perspectives, which greatly enriched his material. Whilst placing him at the social centre of the village of Doolin, County Clare, he also came to be respected as a committed and hard worker, qualities prized in that community. Kaul's considered analysis of his own fieldwork situation strikes a chord with other contributors to this edition who emphasize the element of serendipity in shaping fieldwork and lending orientation to analysis. His remarks also resonate with those of Fumanti, who advocates sensitivity to the very direct forces, which the field may exact on the fieldworker. Finance must be one of the most important considerations in any research project, and Kaul finds early on in his research that it is financial necessity rather than methodological imagination which has become the mother of invention, or rather, the mother of innovative research strategies.

Like Fumanti, Hannah Gill's contribution exemplifies how circumstance, or the will of the field, may entail the necessity not only of radical shifts in approach, but also sea-changes in the actual subject matter of an inquiry. The fieldwork experience in the Dominican Republic which she describes saw her shift research focus swiftly from music and migration to trafficking operations and deportation. Unexpected turns of event cannot be detected even in the most careful re-edits of research development. But Gill implicitly acknowledges that anthropologists own a responsibility to manage the contingencies which arrive unannounced, attached to the stated ambition of a fieldwork proposal. The unpredictable nature of the field requires intellectual and strategic flexibility of the fieldworker.

Kaori O'Connor sees her own research as a response to the intellectual elasticity and impermeability of the modern capitalist system, features which make capitalism a daunting social phenomenon and a difficult entity to access methodologically. She chooses the similarly elastic and impermeable product of Lycra aerobic workout leggings to draw herself into the patterns of production and consumption through which capitalism expresses itself, and which articulate cultural responses to the demographics of the aging baby-boomer cohort. She interprets her strategy as an 
example of what Marcus has described as an 'opportunistic investigation', and draws on the work of Strathern in reinforcing her suggestion that anthropologists should allow themselves to become fascinated, captured and directed by the objects which they encounter.

Ingie Hovland chooses a more experiential route into and through her fieldwork. Perched somewhat uncomfortably on what she feels to be an anthropologically constructed division between 'Home' and 'the Field', she uses Freud's concept of the 'unheimlich' to suggest that ethnographic insight can frequently render the experienced texture of 'home' porous, and even make it prone to rupture. Through her research into The Mission Society in Stavanger, Norway (a society with which she and her family have been closely connected for generations), she compares the diaries of young missionary workers with the narrative devices which have ordered her own life and upbringing. This comparative process renders the familiar disturbing, such that Hovland is forced to examine the premises on which her own life has become familiar to her. The ethnographic perspective dislocates Hovland from herself. It seems that the diaries have exercised their own influence, asserting and even creating moments of intense experiential shift in a research context which initially appeared to offer little that would reward ethnographic study. Initially at a loss as to how to understand her own position in an indeterminate field, Hovland, like the other contributors to this group of papers, finds her research shaped in unpredictable but exciting, and perhaps more importantly, methodologically rewarding ways, by the field itself.

Sometimes research involves very real risks and venturing into new fields can also mean encountering new dangers. George Kunnath who worked with Maoist activists in Bihar decided not to keep a distance to armed activists but opted to 'march with the squats'. He takes safety precautions that included negotiating with the police to escape torture in case of arrest. He is however unsure if these precautions can ensure his wellbeing as a research activist. When a friend is arrested at a demonstration Kunnath turns his back to him, fearing that a spark of recognition could turn the police on to him. Speaking of the 'guilt of the survivor' (referring to Primo Levi) Kunnath examines the complex ethical dilemma of analysing violence outside of what Max Weber defined as the monopoly of the state. Rejecting the exclusivity of state power Kunnath starts his article with the Maoist quest for revolution but ends his article in a critical tone discussing the humanitarian cost of war. Hannah Gill, whose fieldwork also involved violent encounters, dismisses Chagnon's (1968) famous strategy of becoming 'fierce' when informants are or appear to hold a differing concept towards physical force. Instead she establishes a relationship of trust with her host family that eventually allows her to conduct fieldwork in 'relative freedom' in a field of prevalent conflict. She, like many anthropologists before her, accepted that she could not be out alone, complying with the protective restrictions of her host family by accepting a child 'chaperone'.

The complicity of anthropologists with their informants or with existing power structures is dealt with in Stefanie Lotter's article, in which she raises the question of how it is possible for anthropologists to study elites without being uncritically drawn into the elites' presentation of self. She suggests that anthropologists need to be aware of elite groups' potential for self-presentation, but that they can turn this potential to their advantage by using it in order to gain a better understanding of how elite-ness is created. Lotter developed this position in her fieldwork among the Rana clan of Nepal. Although some members of the clan still hold influential positions in politics 
and the military, the Rana as a whole have significantly lost influence since the 1950s, leading to differentiation within the clan in terms of influence, wealth and status. These internal differences presented Lotter with an opportunity to study the selfpresentation of those who still enjoy a degree of privilege and power, comparable to what the clan possessed in the past, from the point of view of those members of the family who are struggling to 'keep up appearances'. This position 'from below' allowed Lotter to gather insights going beyond those to be gained in formal interviews. She considers such interviews problematic because of the elites' commitment to and skill at self-presentation.

This collection of articles, then, creates an opportunity for these anthropologists to explain their relationships to their particular fields. More importantly from a critical perspective, they detail the processes through which particular fields have been brought into being. The fields are made tangible and knowable through paths which anthropology has only recently begun to explore. The articles also carry a pronounced honesty. They show the anthropologist off-guard, caught in the act of improvised, onthe-hoof ethnography, stumbling and tumbling in intellectual, ethical and methodological quagmires. It is hoped that they may therefore provide a discursive and reflexive space for others to consider the lessons, which they as individuals, and as representatives of anthropology as a discipline, have to learn from their experiences in the field.

\section{About the authors}

Tom Rice studied anthropology at Edinburgh and Manchester Universities, and is currently a PhD student at Goldsmiths College, University of London. His particular interest is in the anthropology of the senses, and he is at present working on theories of listening, exploring the development of the 'ethnographic ear'.

Mette Louise Berg teaches in the department of social anthropology at the University of St Andrews. She received her doctorate from the University of Oxford in 2004 on a thesis about the memory of politics and the politics of memory among diasporic Cubans in Spain. She was chair of the Oxford University Anthropological Society (OUAS) in 2002-2003, and organised the Future Fields conference.

E-mail: mette.berg@st-andrews.ac.uk 